\title{
What is Happening to the Parks of the Uncompahgre Plateau?
}

\author{
MARLIN H. JENSON
}

$\mathrm{P}$ arks are openings in a forest and sometimes referred to as meadows. In these places grasses and forbs are the largest part of the biological community. In the temperate climates of Colorado species like oatgrass, Idaho fescue, blue eyed-grass and yarrow are found growing in parklands. Within a forested landscape, parklands offer a unique and important set of values. For example, forage produced in parks is a critical component of the elk and deer habitat. Similarly, when included in livestock grazing allotments the lion's share of a pasture's carrying capacity comes from parklands. Parks are sought out by cattle and sheep, and often are among the first places to be grazed in fresh pastures. Open space available in parks provide year-round recreation opportunities. Photography, sightseeing, camping, and snowmobiling are just a few of the activities available on these lands. Consequently, parks are places where competition between different uses is first noticed.

The Uncompahgre plateau is a prominent feature of the landscape in western Colorado. An aspen and spruce-fir forest covers the top of the plateau. Parks were once common throughout this forest. Those that remain are a welcome relief from the monotony of the forest where trees and shrubs like Engelmann spruce and shrubby cinquefoil control the landscape. Soils in these parklands are moderately deep and these are well drained with a cobbly loam texture. The elevation of these parks ranges from 8,400 to 9,300 feet above sea level and the average annual precipitation is 23 inches. Most of this precipitation falls during the winter months.

Fifty years ago, within this setting, Forest Ranger Leslie Burton established a protection exclosure at Johnson Park. The area protected was slightly over one acre in size. It was protected by a worm fence constructed from aspen poles. The structure formed a square and extended 210 feet on each side. In 1949 it was given official status and named Johnson Park Range Observation Plot.

Interestingly, Burton indicated that aspen was invading portions of the exclosure in a 1949 memo. He described the purpose of the structure by stating that it was "to provide an ocular and photographic comparison of grazed and ungrazed ranges...and to determine the relative influence that protection and use have on range condition and trend." Shortly after its construction Staff Assistant Kenneth J. Cross established a permanent camera point. His photographs of the exclosure were taken on July 14,1949 . Photographs were retaken in 1954, 1959 and 1964 by others who followed Cross. After 1964, range management personnel would not visit the site again until 1999. Sadly, the record indicates that Burton's purposes for the project were never realized.
When the site was again visited some thirty-five years later, the question foremost in the minds of range personnel was: "How has this wild land community changed in the last fifty years?" Photographs were retaken, the distance of the aspen stand from the photo point and canopy cover of the vegetation was measured, and the density of the aspen stand was determined. Evidence gathered from these sources show that a dramatic change in the vegetation is taking place on this parkland.

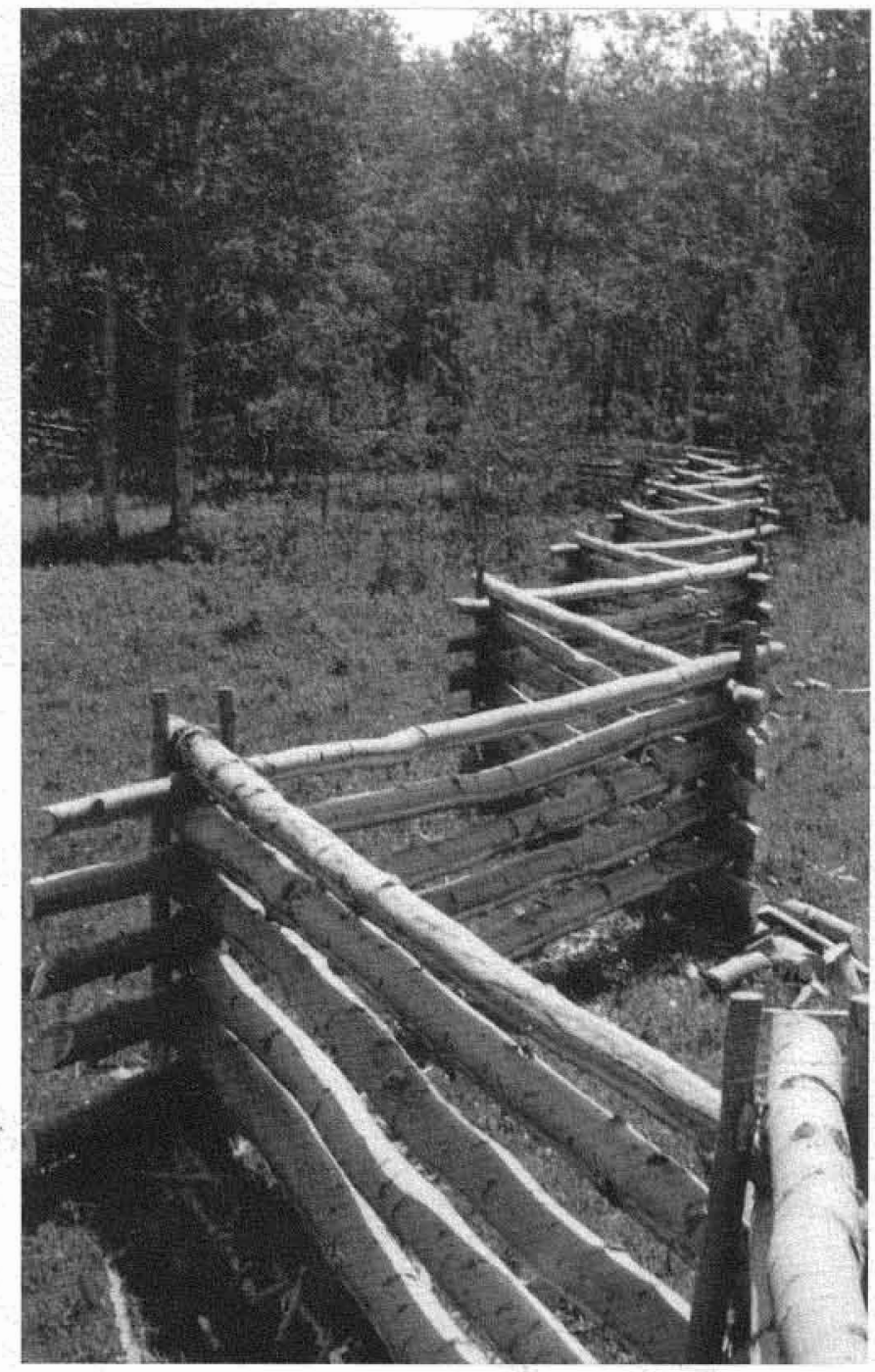

Photo one. Johnson Park Range Study Plot, Dave Wood Allotment. Permanent Photo No. 459348 taken by Kenneth J. Cross July 14, 1949. 


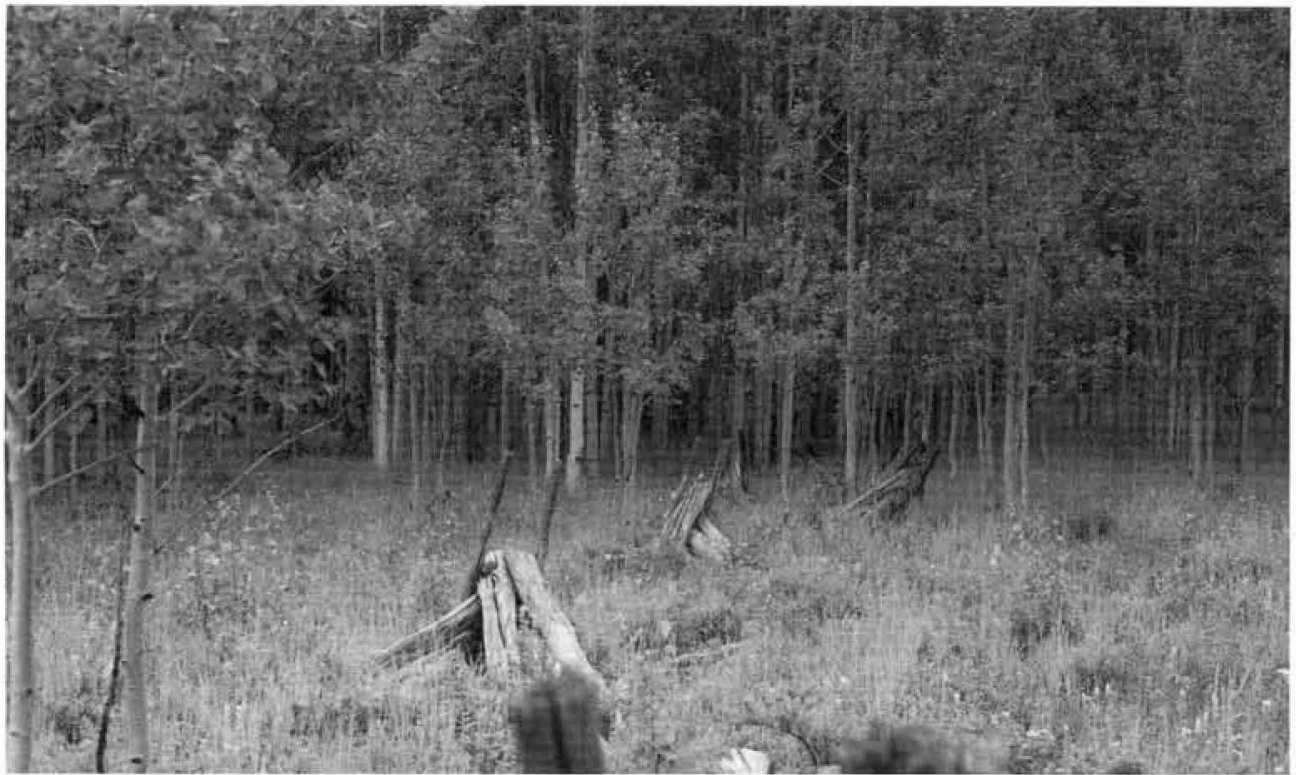

Photo two. Johnson Park Range Study Plot, Dave Wood Allotment. Permanent Photo No. 459348 retaken by Marlin Jenson on August 3, 1999.

The 1949 photo shows a large area of parkland before entering the aspen stand (photo 1). By contrast the 1999 photo shows a very small area of parkland before entering the aspen (photo 2). Clearly, the aspen has moved closer to the photo point and now occupies an area that once was a meadow. By counting the number of fence panels on the worm fence beginning at the photo point, the location of the edge of the aspen stand can be determined when the fence was constructed in 1949. A careful examination of the 49 photo shows that aspen suckers are approximately 7 fence panels from the photo point, a distance of 90.8 feet. When the site was inspected in 1999, aspen suckers were found within 12.5 feet of the photo point. The difference between the two measurements represents the distance the aspen stand has advanced into the meadow. This distance is equal to 78.3 feet, meaning that the aspen is moving into the meadow at a rate of 1.5 feet per year ( 78.3 feet $\div 50$ years).

To better understand how the community has changed at the edge of the park the canopy cover of the vegetation in the new aspen stand was measured and compared with that in the meadow during the ' 99 visit. A Daubenmire frame with six cover classes was used to make these measurements. Twenty plot frames were read in the young aspen stand and another twenty were read in the parkland on August 8, 1999. Canopy cover of grasses and forbs is significantly higher in the parkland as shown in Table 1, whereas canopy cover of shrubs and trees is greater in the aspen grove.

Table 1

Average Canopy Cover (\%)

\begin{tabular}{||l|c|c||}
\hline \hline Component & $\begin{array}{c}\text { Young Aspen } \\
\text { Stand }\end{array}$ & Parkland \\
\hline Grasses & $14 \%$ & $26 \%$ \\
\hline Forbs & $25 \%$ & $43 \%$ \\
\hline Shrubs & $71 \%$ & $38 \%$ \\
\hline Trees & $25 \%$ & 0 \\
\hline
\end{tabular}

The density of the trees was measured by simply counting the number of aspen tree stems on a tenth of acre plot. Eightyseven tree stems were counted in this exercise. Instead of supporting a community dominated by grasses and forbs as it most likely did in 1949, the area at the edge of the park now supports about 870 young aspen trees per acre with a dense under story of shrubs.

Based on the photographic and numerical data it seems reasonable to conclude that the composition of the vegetation at Johnson Park is changing. During the summer months of 1999 other places on the Uncompahgre Plateau were visited and aspen suckers were found creeping out into the area occupied by parklands. These observations together with the evidence collected at Johnson Park lead to the conclusion that like many things in nature, the communities of the Uncompahgre are slowly changing. These changes are subtle and not easily noticed. Accordingly, parklands of the Uncompahgre are gradually shrinking as the size of the forest expands.

One of the first lessons learned by students of range science is that ecology is the study of organisms at home. On the Uncompahgre, the house is still there but the residences are changing.

\section{Notes}

Burton, Leslie. 1949. US Forest Service memo regarding the Johnson Park Range Observation Plot. Montrose, CO. 16 Nov.

Jenson, Marlin H. 1999. Field Notes, 8 \& 11 August and 29 October.

Odum, Eugene P. 1971. Fundamentals of Ecology. Philadelphia: W. B. Saunders CO.

USDA Forest Service and Soil Conservation Service. March, 1995. Soil Survey of the Uncompahgre National Forest Area, Colorado, Parts of Mesa, Montrose, Ouray and San Miguel Counties. Prepared in cooperation with the Colorado Agricultural Experiment Station and Colorado State University.

USDA Forest Service. 1996. Rocky Mountain Region. Denver, CO. Rangeland Analysis and Management Training Guide. 5 August.

Author is a range conservationist for the Ouray Ranger District: Grand Mesa, Uncompahgre and Gunnison National Forest. 